\title{
ANALISIS FAKTOR YANG MEMPENGARUHI KUNJUNGAN WISATAWAN MANCA NEGARA KE INDONESIA
}

\author{
Wawan Hermawan \\ Adhitya Wardhana \\ CEDS FEB Universitas Padjadjaran Bandung \\ Jl. Cimandiri No. 8 Bandung. Telp. 022-4204510 \\ Email: wawan.hermawan@fe.unpad.ac.id
}

\begin{abstract}
The tourism sector is a sector that can be relied on to earn foreign exchange. Revenue from tourism showed significant progress and continues to grow, so bring a high impact on the Indonesian economy. Number of tourists visiting foreign countries is an important indicator for the growth of tourism sector in Indonesia is related to the increase in foreign exchange. Increase or decrease of tourist arrivals is influenced both by internal factors such as the condition of tourist destinations in Indonesia, politics and security in Indonesia or external factors such as the economic conditions of the various countries of origin of foreign tourists. This study uses panel data with the annual number of tourist arrivals from a number of countries to Indonesia for 19 years as the dependent variable. The independent variable of this research is RGDPP (Real GDP Per Capita), RREER (Relative Real Effective Exchange Rate), TCPI (Indicative Ratio of Consumer Price Index), Population, CPITUNIS (Consumer Price Index Tunisia), TO (Trade Openness). The results of this study indicate that tourist arrivals to Indonesia is heavily influenced by the distance from their home country to destinations in Indonesia. This variable is the biggest variable affecting the arrival of foreign tourists to Indonesia. Income per capita is the second largest variable and has a coefficient close to unity, so that the income elasticity of country of origin is an important variable to be considered.
\end{abstract}

Key words: Tourism, Foreign Exchange

QE Journal | Vol.05 - No. 01 March 2016 - 16 


\section{PENDAHULUAN}

$K$

unjungan wisatawan mancanegara ke Indonesia memberikan dampak positif bagi perekonomian Indonesia melalui permintaan atas barang dan jasa domestik yang berkaitan dengan sektor pariwisata. Pendapatan devisa yang dihasilkan dari pengeluaran para wisatawan mancanegara merupakan pendapatan penting bagi negara dalam menjalankan perdagangan terbuka dengan pasar internasional. Semakin besar jumlah wisatawan manca negara, maka harapan dari pertumbuhan ekonomi yang disebabkan oleh pengeluaran para wisatawan mancanegara di berbagai destinasi di seluruh Indonesia dapat menjadi salah satu penopang yang kuat bagi perkembangan kesejahteraan masyarakat Indonesia.

Menurut Kementerian Pariwisata dan Ekonomi Kreatif pada tahun 2013, menjelaskan kontribusi sektor pariwisata dalam perolehan devisa Indonesia pada periode 2008-2012 mengalami perkembangan. Sektor pariwisata memiliki rangking ke empat dalam total ekspor Indonesia pada tahun 2013 yang sebesar 10,054 juta Dollar Amerika. Peranan sektor pariwisata terhadap PDB nasional di tahun 2011 sebesar Rp. 296,97 triliun, 4,00 dari PDB Nasional (LAKIP, Kementrian Pariwisata dan Ekonomi Kreatif, 2012) perkembangan pariwisata Indonesia dapat dilihat pada Tabel 1.

Sumbangan sektor pariwisata terhadap PDB pada tahun 2012 sebesar 326.24 triliun rupiah dan tahun sebelumnya mengalami peningkatan hingga tahun 2012 (Tabel 2.) Besarnya kontribusi sektor pariwisata membuat ekonomi makro Indonesia terus mengalami peningkatan. Sektor pariwisata yang mengalami perkembangan akan mendorong ekonomi makro Indonesia menjadi lebih baik. Dampak positif ini tidak terlepas dari meningkatnya jumlah kunjungan wisatawan mancanegara ke Indonesia dari tahun ke tahun.

Menurut data BPS tahun 2013, kedatangan wisatawan mancanegara meningkat dalam setiap tahun. Pada tahun 2009, wisatawan mancanegara yang datang ke Indonesia sebesar 6.323 .730 orang, dan angka ini terus meningkat sampai dengan tahun 2013. Perkembangan ini mengindikasikan Indonesia sangat diminati oleh wisatawan untuk berlibur.

QE Journal | Vol.05 - No. 01 March 2016 - 17 
Tabel 1. Andil Pariwisata dan Komoditas Lainnya Ditinjau dari Perolehan Devisa Indonesia Tahun 2011-2013

\begin{tabular}{|c|c|c|c|c|c|c|}
\hline \multirow{2}{*}{$\begin{array}{c}\text { Uruta } \\
\mathrm{n}\end{array}$} & \multicolumn{2}{|c|}{2011} & \multicolumn{2}{|c|}{2012} & \multicolumn{2}{|l|}{2013} \\
\hline & Komoditas & Nilai & Komoditas & Nilai & Komoditas & Nilai \\
\hline & Minyak \& Gas & & Minyak \& Gas & 36,977 . & & \\
\hline 1 & Bumi & $41,477.1$ & Bumi & $\begin{array}{r}0 \\
26166\end{array}$ & Minyak \& Gas Bumi & $32,633.2$ \\
\hline 2 & $\begin{array}{l}\text { Batu bara } \\
\text { Minyak Kelapa }\end{array}$ & $27,221.8$ & $\begin{array}{l}\text { Batu bara } \\
\text { Minyak Kelapa }\end{array}$ & $\begin{array}{r}3 \\
18,845 .\end{array}$ & Batu bara & $24,501.4$ \\
\hline 3 & Sawit & $17,261.3$ & Sawit & $\begin{array}{r}0 \\
10,394 .\end{array}$ & Minyak Kelapa Sawit & $15,839.1$ \\
\hline 4 & Karet olahan & $14,258.2$ & Karet olahan & 5 & Pariwisata & $10,054.1$ \\
\hline 5 & Pariwisata & $8,554.4$ & Pariwisata & $9,120.8$ & Karet olahan & $9,316.6$ \\
\hline 6 & Pakaian Jadi & $7,801.5$ & Pakaian Jadi & $7,304.7$ & Pakaian Jadi & $7,501.0$ \\
\hline 7 & Alat Listrik & $7,364.3$ & Alat Listrik & $6,481.9$ & Alat Listrik & $6,418.6$ \\
\hline 8 & Tekstil & $5,278.1$ & Tekstil & $5,278.1$ & Makanan Olahan & $5,434.8$ \\
\hline
\end{tabular}

Sumber: Badan Pusat Statistik, 2013

Peningkatan atau penurunaan dari kunjungan wisatawan mancanegara dipengaruhi baik oleh faktor internal berupa kondisi destinasi wisata di Indonesia, politik dan keamanan di Indonesia atau faktor eksternal berupa kondisi ekonomi dari berbagai negara asal wisatawan mancanegara. Variabel-variabel eksternal, terutama mempengaruhi permintaan atas kunjungan wisata ke Indonesia, sehingga diperlukan berbagai analisis atas faktor-faktor yang dapat mempengaruhi kunjungan wisatawan mancanegara ke Indonesia. Berdasarkan uraian di atas, maka tujuan dari kajian ini adalah mendapatkan hasil analisis atas faktor-faktor yang mempengaruhi kunjungan wisatawan mancanegara ke Indonesia.

Menurut Pitana (2009), terdapat empat atribut dalam konteks perilaku wisatawan yang bisa diterima secara luas, diantaranya wisatawan merupakan orang yang melakukan perjalanan yang jauh dari tempat tinggalnya yang datang suatu tempat atau negara lain, perjalanan wisata yang dilakukan memiliki durasi minimum dan bersifat sementara, mengunjungi tempat lain yang dituju tidak untuk menetap, perilaku wisata timbul dalam waktu senggang dan perjalanan wisata menghubungkan rasa emosional antara wisatawan dengan beberapa karakteristik tempat yang dikunjungi. 
Tabel 1. Kontribusi Pariwisata Terhadap PDB, Tenaga Kerja, Gaji dan Pajak Indonesia Tahun 2011-2012

\begin{tabular}{ccccccccc}
\hline & \multicolumn{2}{c}{ PDB } & \multicolumn{2}{c}{ Tenaga Kerja } & \multicolumn{2}{c}{ Upah / Gaji } & \multicolumn{2}{c}{ Pajak Tidak Langsung } \\
Tahun & Nilai & Share (\%) & Nilai & Share (\%) & Nilai & Share (\%) & Nilai & Share (\%) \\
\hline 2009 & 233.89 & 4.17 & 6.98 & 6.68 & 75.54 & 4.7 & 8.36 & 4.19 \\
2010 & 261.06 & 4.06 & 7.44 & 6.87 & 84.8 & 4.63 & 9.35 & 4.16 \\
2011 & 296.97 & 4 & 8.53 & 7.75 & 96.57 & 4.14 & 10.72 & 3.85 \\
2012 & 326.24 & 3.96 & 9.35 & 8.46 & 105.93 & 4.12 & 11.77 & 3.82 \\
\hline
\end{tabular}

Sumber : Kementrian Pariwisata dan Ekonomi Kreatif, 2012

Keterangan : PDB dalam triliun rupiah dan Tenaga kerja dalam juta orang

Cohen dalam Pitana (2009), terdapat klasifikasi wisatawan berdasarkan tingkat familiarisasi dari daerah yang akan dikunjungi dan tingkat pengorganisasian dari perjalanan wisatanya. Kemudian Cohen membuat perbedaan wisatawan menjadi empat, yaitu Drifter, yaitu wisatawan yang ingin mengunjungi tempat yang sama sekali belum diketahuinya dengan bepergian dalam kuantitas rendah, Explorer, yaitu wisatawan yang melakukan perjalanan dengan mengatur perjalanannya sendiri dan tidak melakukan perjalanan wisata yang sudah umum, Individual mass tourist, yaitu wisatawan yang bepergian menurut agen perjalanan, dan mengunjungi daerah wisata yang sudah terkenal, Organized mass tourist, yaitu wisatawan yang mengunjungi daerah wisata sudah terkenal, fasilitas yang ditemui di tempat tinggalnya dan perjalanannya dipandu oleh pemandu wisata.

Kegiatan pariwisata akan menimbulkan kegiatan-kegiatan yang berkaitan dengan konsumsi dan produksi barang dan jasa yang terlibat dalam kegiatan pariwisata. Industri pariwisata tidak berdiri sendiri, tetapi industri dari serangkaian perusahaan yang menghasilkan jasa atau produk yang berbeda satu dengan lainnya. Perbedaan itu tidak hanya jasa selalu dihasilkan, tetapi dalam besarnya perusahaan, lokasi, organisasi yang mengelola dan cara pemasaran (Tahwin, 2003).

Suatu industri pariwisata sulit untuk diukur, hal ini dikarenakan tidak adanya standar nomor klasifikasi industri, tetapi keberadaan pariwisata memiliki nilai jual tertentu dan memberikan dampak positif bagi perekonomian terutama multiplier effect. Jadi pariwisata dapat dianggap 
sebagai suatu industri. Menurut Pragojo (1976), bahwa perkembangan pariwisata berdampak ganda terhadap sektor-sektor lain, seperti transportasi, perhotelan, restoran, dan lain-lain.

Permintaan pariwisata yaitu sesuatu yang menghubungkan jumlah wisatawan (Wahab, 2003). Permintaan pariwisata dibagi menjadi permintaan yang potensial dan permintaan yang sebenarnya. Permintaan potensial merupakan jumlah orang yang berpotensi melakukan perjalanan wisata. Permintaan sebenarnya adalah orang yang berkunjung pada suatu daerah tujuan wisata, artinya wisatawan yang secara nyata sedang berkunjung pada suatu daerah wisata.

Shomol dalam Yoeti (2008) menunjukkan faktor-faktor yang menentukan permintaan terhadap daerah kunjungan wisata yaitu, harga, daya tarik wisata, fasilitas yang tersedia, pelayanan lainnya (seperti transportasi lokal, hiburan, dan lain-lain), infrastruktur wisata yang memadai seperti sarana jalan, jembatan, tenaga listrik dan air bersih, informasi umum terhadap daerah wisata sebelum wisatawan melakukan perjalanan wisata dan performa wisata.

Beberapa penelitian terdahulu yang mendukung penelitian ini, seperti penelitian yang dilakukan oleh Ibrahim (2011). Penelitian Ibrahim (2011) meneliti faktor-faktor yang mempengaruhi wisatawan mancanegara untuk berwisata ke Mesir. Dasar teori yang digunakan dalam penelitian ini yaitu teori ekonomi klasik yang berasumsi bahwa pendapatan dan faktor harga berperan dalam penentuan faktor yang mempengaruhi permintaan pariwisata.

Penelitian ini menggunakan annual panel data dengan data jumlah kedatangan wisatawan dari sejumlah negara ke Mesir selama 19 tahun sebagai variabel dependennya. Variabel independen penelitian ini yaitu RGDPP (Real GDP Per Capita), RREER (Relative Real Effective Exchange Rate),TCPI (Indicative Ratio of Consumer Price Index), Populasi, CPITUNIS (Consumer Price Index Tunisia),TO (Trade Openness). Persamaan dari penelitian dapat dijabarkan sebagai berikut: 


$$
\begin{aligned}
\log \left(\mathrm{TA}_{\mathrm{it}}\right)=\beta_{0} & +\beta_{1} \log \left(\mathrm{POP}_{\mathrm{it}}\right)+\beta_{2} \log \left(\mathrm{RGDPP}_{\mathrm{it}}\right)+\beta_{3} \log \left(\mathrm{TCPI}_{\mathrm{it}}\right) \\
& +\beta_{4} \log \left(\mathrm{RREER}_{i t}\right)+\beta_{5} \log \left(\mathrm{TO}_{\mathrm{it}}\right)+\beta_{6} \log \left(\mathrm{CPITUNIS}_{\mathrm{t}}\right)+\mathrm{u}_{\mathrm{i}}
\end{aligned}
$$

$\mathrm{TA}_{\text {it }}$ merupakan kedatangan wisatawan ke mesir dari negara i pada waktu $\mathrm{t}, \beta_{0}$ adalah konstanta, RGDPP it adalah real GDP per Capita negara i pada waktu t, TCPI ${ }_{i t}$ adalah Indicative Ratio of Consumer Price Index negara i pada waktu $\mathrm{t}\left(\right.$ TCPI $\left._{i t}=\frac{\text { CPIEgypt }_{t}}{\text { CPI }_{i t}}\right), \quad \mathrm{POP}_{\mathrm{it}}$ adalah populasi penduduk negara $\mathrm{i}$ pada waktu t, RREER ${ }_{i t}$ adalah Relative Real Effective Exchange Rate negara i pada waktu $\mathrm{t}\left(R R E E R_{i t}=\frac{R R E E R E g y p t_{t}}{R R E E R_{i t}}\right)$, CPITUNIS $_{\mathrm{t}}$ adalah Consumer Price Index Negara Tunisia pada waktu $\mathrm{t}, \mathrm{u}_{\mathrm{i}}$ adalah error term, $\mathrm{TO}_{\mathrm{it}}$ adalah Trade Openness negara i pada waktu $\mathrm{t}\left(\mathrm{TO}_{i t}=\frac{\left(\text { Ekspor }_{i t}+\text { Impor }_{i t}\right)}{\text { GDPEgypt }_{t}}\right)$, Kesimpulan penelitian ini menunjukkan, bahwa umumnya variabel dalam model berpengaruh secara signifikan dengan teori permintaan. Variabel populasi tidak konsisten dengan teori permintaan, hal ini variabel populasi berpengaruh negatif dengan kedatangan wisatawan.

Penelitian Seetanah et al., (2011), kedatangan wisatawan ke Mauritius periode 1985 - 2006 dari wisatawan Eropa, Amerika Serikat, Asia, dan Afrika. Tujuan penelitian ini untuk mengetahui faktor penentu dalam menjelaskan keberhasilan dari daerah tujuan wisata internasional. Penelitian ini membahas fungsi pariwisata internasional dengan memasukkan proxy infrastruktur. Data penelitian dibagi menjadi tiga set panel yaitu benua (Eropa/Amerika, Asia dan Afrika ) untuk membandingkan penentu kedatangan wisatawan dari berbagai benua dengan tujuan Mauritius. Variabel harga pariwisata (IHK) sebagai penentu kedatangan wisatawan, pendapatan negara asal, jumlah kamar hotel, jarak, dan infrastruktur dengan model:

$$
\mathrm{TR}_{\mathrm{it}}=\alpha_{0}+\alpha_{1} \text { relativeit }+\alpha_{2} \mathrm{gdpf}_{\mathrm{it}}+\alpha_{3} \text { room }_{\mathrm{it}}+\alpha_{4} \text { distanceit }+\alpha_{5} \text { infrasit }_{\mathrm{in}}+\varepsilon_{\mathrm{i}}
$$

Penelitian ini terhitung sekitar 90\% dari total kedatangan dan modal infrastruktur memiliki efek positif pada jumlah kedatangan wisatawan serta pada kedatangan dari tiga wilayah tersebut. Hasil ini konsisten dengan gagasan karena penduduk negara maju terbiasa dengan infrastruktur modern berkualitas tinggi. Variabel kamar, diproksikan sebagai infrastruktur pariwisata yang menunjukkan peningkatan jumlah hotel akan menghasilkan lebih banyak jumlah kedatangan wisatawan. 
Penelitian Habibi dan Abbasinejad (2011) mengidentifikasi dampak penentu utama kedatangan wisatawan internasional ke Malaysia dengan menggunakan data panel tahunan meliputi jumlah kedatangan dari19 negara Eropa selama periode1998-2007 dengan model penelitian :

$\Delta \ln \mathrm{TAi}, \mathrm{t}=\beta 1 \Delta \ln \mathrm{TAi}, \mathrm{t}-1+\beta 2 \Delta \ln \mathrm{GDPi}, \mathrm{t}+\beta 3 \Delta \ln \mathrm{TPt}+\beta 4 \Delta \ln \mathrm{TPSj}, \mathrm{t}+$ $\beta 5 \Delta \ln \mathrm{HRt}+\beta 6 \Delta \ln \mathrm{PSt}+\beta 7 \Delta \mathrm{D} 2000+\beta 8 \Delta \mathrm{D} 2003+\mathrm{i}, \mathrm{t}$

Hasil penelitian ini menunjukkan variabel kedatangan turis (lag TA), pendapatan (GDP), harga relative (TP), jumlah kamar hotel (HR) dan stabilitas politik (PS) memiliki pengaruh positif terhadap permintaan pariwisata Eropa di Malaysia. Estimasi data panel dinamis memperhatikan kapasitas wisatawan yang datang ke Malaysia

\section{METODE PENELITIAN}

Penelitian ini menganalisis faktor-faktor yang mempengaruhi kunjungan wisatawan mancanegara ke Indonesia. Faktor-faktor yang digunakan dalam penelitian ini, yaitu jumlah kedatangan wisatawan asing, tingkat PDB per Kapita, nilai promosi pariwisata, kurs riil, jarak negara dan jumlah penduduk negara asal. Periode penelitian yang akan diteliti adalah yang dipilih untuk observasi dalam penelitian ini adalah tahun 2011 sampai 2014.

Teknik analisis dalam penelitian ini menggunakan analisis kualitatif dan analisis kuantitatif. Analisi kualitatif seperti studi literatur, buku, dan artikel yang sesuai dengan topik penelitian ini untuk dijadikan sebagai acuan. Analisis kuantitatif dalam bentuk model ekonometrika agar dapat menjelaskan hubungan antar variabel. Wilayah yang akan diteliti yaitu 11 negara ASEAN diantaranya : Singapura, Malaysia, Philipana, Thailand, Australia, China, Jepang, Korea Selatan, Taiwan, India dan Hongkong. Penelitian ini menggunakan data panel.

Aplikasi dari model permintaan di atas dicoba untuk diterapkan pada model permintaan untuk destinasi wisata di Indonesia terhadap Kunjungan Wisatawan Macanegara. Model persamaan Kunjungan Wisatatawan Mancanegara dibuat untuk melihat bagaimana perilaku dari Kunjungan Wisatawan Mancanegara dilihat dari variabel Pendapatan yang diproksi oleh GDP Per Kapita, Biaya Promosi, Harga yang diproksi dari 
Kurs Riil, Jarak dan Populasi. Semua variabel merupakan data untuk 11 negara sampel, yaitu : Singapura, Malaysia, Philipana, Thailand, Australia, China, Jepang, Korea Selatan, Taiwan, India dan Hongkong. Bentuk persamaan untuk estimasi Kunjungan Wisatawan Mancanegara dapat ditunjukkan sebagai berikut:

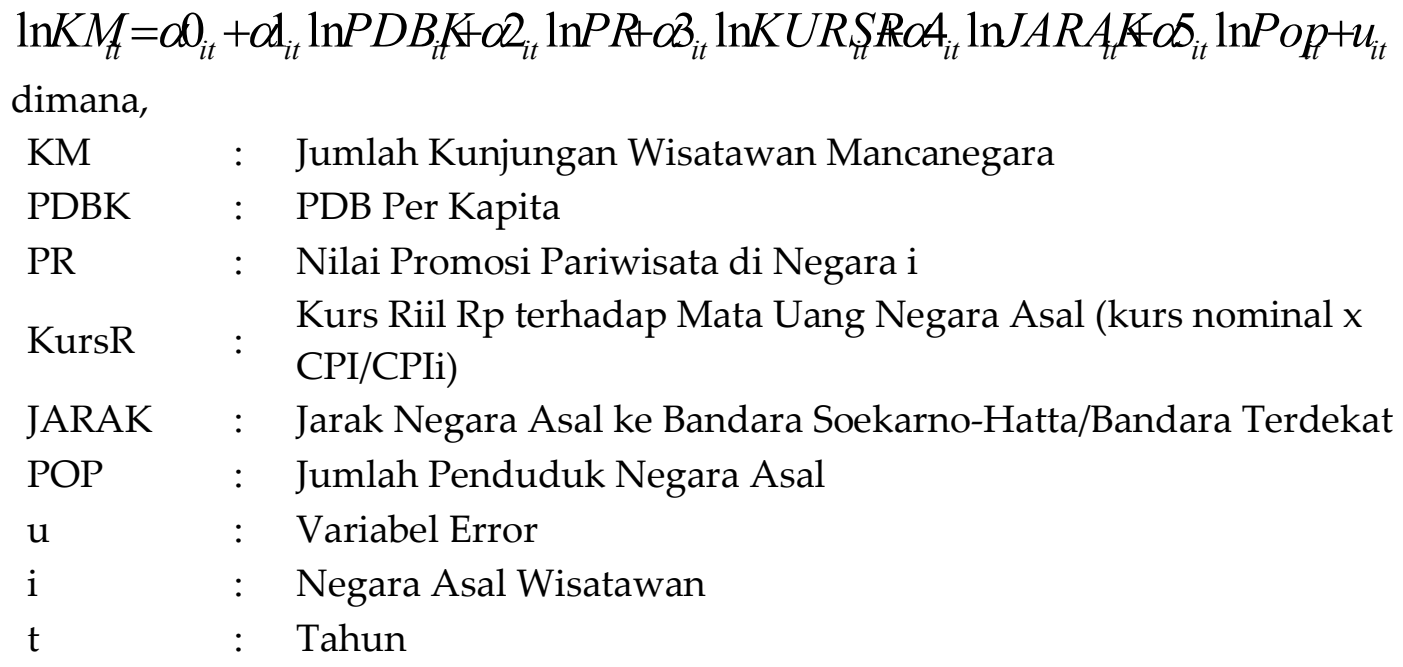

Dalam menentukan model diantara dua model fixed effect atau random effect dengan menggunakan uji hausman. Uji hausman merupakan dasar pertimbangan kita untuk memilih fixed effect model atau random effect model. Hasil uji autokorelasi, heteroskedastis dan multikolinieriti menunjukkan hasil yang baik dan layak untuk dianalisis lebih lanjut.

\section{HASIL DAN PEMBAHASAN}

Analisis untuk data panel pada negara yang mempunyai kunjungan wisata terbesar ke Indonesia digunakan Random Effect. Cara ini terpilih setelah uji Hausman yang menunjukkan penggunaan Random Effect dibandingkan dengan Fixed Effect. Hasil estimasi ditunjukkan pada tabel berikut:

Hasil random effect untuk variabel kunjungan wisatwan sebagai variabel dependen diperlihatkan sebagai berikut. 


$\begin{array}{llllll}\text { C } & \text { LNPDBK }_{i t} & \text { LNPR }_{i t} & \text { LNKURSR }_{i t} & \text { LNJARAK }_{i t} & \text { LNPOP }_{i t} \\ 14.77^{* * *} & 0.84^{* * *} & 0.04^{* *} & -0.02 & -1.54^{* * *} & 0.65^{* * *} \\ (3.60) & (0.10) & (0.02) & (0.10) & (0.46) & (0.16)\end{array}$

$\mathrm{R}^{2}: 0.71 ; \mathrm{DW}: 2.8$

Keterangan:

LNKM : Jumlah Kunjungan Wisatawan Mancanegara

LNPDBK : PDB Per Kapita

LNPR : Nilai Promosi Pariwisata di Negara i

LNKursR : : Kurs Riil Rp terhadap Mata Uang Negara Asal

LNJARAK : Jarak Negara Asal ke Bandara Soekarno-Hatta/Bandara Terdekat

LNPOP : Jumlah Penduduk Negara Asal

i : Negara Asal Wisatawan

t : Tahun

Hasil estimasi di atas telah lolos untuk uji Klasik, berupa uji autokorelasi, uji Heteroskedastis dan uji Multikolinearitas. Hasil ini menunjukkan hasil yang cukup bagus, dimana variabel kurs riil tidak mempengaruhi atas total kunjungan dari negara-negara yang menjadi observasi. Selain dari variabel kurs, empat variabel lainnya mempengaruhi variabel kunjungan wisatawan mancanegara secara signifikan.

Variabel pendapatan perkapita merupakan variabel yang mempunyai pengaruh terbesar kedua setelah jarak terhadap kunjungan wisatawan manca negara. Kenaikan dari pendapatan per kapita sebesar satu persen, mampu meningkatkan kunjungan wisatawan manca negara sebesar 0.8 persen. Angka ini tidak elastis, tetapi cukup besar dalam meningkatkan pertumbuhan wisatawan manca negara. Hal ini juga sekaligus merupakan sebuah sinyal, bahwa negara-negara dengan potensi pendapatan tinggi diharapkan dapat datang ke berkunjung ke wisatawan dengan tingkat yang lebih tinggi. Selain itu, kenaikan ekonomi dari negara-negara asing memberikan dampak positif atas kenaikan kunjungan wisatawan manca negara ke Indonesia.

Promosi wisata yang dilakukan oleh kementerian Pariwisata beserta dinasdinas pariwisata daerah telah terbukti memiliki pengaruh yang siginifikan 
terhadap kunjungan wisatawan mancanegara. Pengaruh yang terjadi kecil, atau hanya $0.04 \%$ tambahan wisatawan mancanegara tiap kenaikan satu persen biaya promosi yang dikeluarkan pemerintah. Walau bagaimanapun, kenaikan dari kunjungan wisatawan mancanegara akibat dari adanya biaya promosi menjadi sebuah acuan atas peningkatan jumlah wisatawan dengan melakukan kegiatan promosi.

Variabel kurs riil dari setiap negara wisatawan mancanegara terhadap Rupiah tidak menunjukkan hasil yang signifikan. Tanda yang negatif menunjukkan arah yang konsisten terhadap peningkatan wisatawan sebagai akibat dari pelemahan rupiah. Keadaan ini menimbulkan sebuah fenomena bahwa perubahan kurs yang terjadi terhadap rupiah dari masing-masing negara asal wisatawan tidak menjadi masalah atas kunjungan wisatawan mancanegara. Kemungkinan lain adalah, kunjungan wisatawan ini sudah merupakan rencana jauh-jauh hari. Artinya perubahan kurs yang terjadi kemudian tidak menyurutkan rencana kunjungan yang sudah direncanakan.

Variabel jarak mempunyai tanda negatif yang memberikan arti adanya hubungan terbalik antara jumlah kunjungan wisatawan mancanegara dengan jarak dari asal negara tiap wisatawan terhadap destinasi di Indonesia. Koefisien dari variabel ini merupakan koefisien terbesar dan menunjukkan elastisitas yang cukup tinggi. Jika terjadi peningkatan jarak dari destinasi di Indonesia terhadap asal negara wisatawan sebesar satu persen, maka terjadi penurunan jumlah kunjungan wisatawan sebesar 1,5 persen.

Populasi sebagai variabel terakhir dari model memiliki koefisien sebesar 0.65 yang menunjukkan besar pengaruh dari banyaknya populasi di tiap negara asal wisatawan terhadap jumlah kunjungan wisatawan. Setiap terjadi kenaikan populasi dari negara asal sebesar satu persen akan meningkatkan jumlah kunjungan wisatawan sebesar 0.65 persen. Besar populasi memberikan kemungkinan lebih tinggi dari jumlah kunjungan wisatawan, semakin besar populasi akan memberikan jumlah masyarkat dari populasi tersebut untuk melakukan perjalana wisata, termasuk ke Indonesia.

\section{SIMPULAN DAN SARAN}

QE Journal | Vol.05 - No. 01 March 2016 - 25 
Kunjungan wisatawan mancanegara ke Indonesia banyak dipengaruhi oleh jarak tempuh dari negara asal mereka ke destinasi-destinasi di Indonesia. Variabel ini merupakan variabel terbesar yang mempengaruhi kedatangan wisatawan mancanegara ke Indonesia. Pendapatan perkapita merupakan variabel kedua terbesar dan mempunyai koefisien yang mendekati satu. Hal ini menunjukkan tingkat kesejahteraan negara asal wisatawan merupakan variabel yang banyak berperan dalam mempengaruhi kunjungan wisatawan mancanegara. Variabel promosi wisata yang dilakuka oleh pemerintah turut andil dalam mempengaruhi kunjungan wisatawan, walaupun pengaruhnya relatif rendah. Berbeda dengan variabel populasi yang mempunyai pengaruh yang lebih besar dibandingkan dengan promosi terhadap kunjungan wisawatan mancanegara. Variabel kurs riil tidak mempengaruhi kinjungan wisatawan mancanegara ke Indonesia.

\section{DAFTAR PUSTAKA}

Gegel, I Putu. (2006). Industry Pariwisata Indonesia : Dalam Globalisasi Perdagangan Jasa GATS WTO, Rafika Aditama, Bandung

Gujarati, D. N. 2009. Basic Econometrics Fifth Edition. Edited by McGrawhill. Canada.

Habibi, F., \& Rahim, K. A. 2009. A Bound Test Approach to Cointegration of Tourism Demand.American Journal Of Applied Science.

Husaen Hasan, Muhammad Asdar, Jusni Faktor-Faktor Yang Mempengaruhi Keputusan Wisatawan Dalam Melakukan Kunjungan Wisata Di Kota Tidore Kepulauan, Fakultas Ekonomi, Universitas Hasanuddin, Makassar

Ibrahim, 2011, The Determinants of International Tourism Demand for Egypt: Panel Data Evidence, European Journal of Economics, Finance and Administrative Sciences, ISSN 1450-2275 Issue 30 (2011)

Juli Doy, Steven (2009), Analisis Faktor-Faktor yangMempengaruhi PerilakuWisatawan Mancanegara dalam Pengambilan Keputusan Pembelian Produk Kerajinan KulitMotifWayang (Tatah Sungging), Jurnal Fakultas Ekonomi, Universitas Gunadarma 
Pitana, I.G, Diarta, I.K.G. 2009. Pengantar Ilmu Pariwisata. Yogyakarta: Andi Publisher.

Prajogo, M.J. 1976. Pengantar Pariwisata Indonesia. Jakarta: Direktorat Jendral Pariwisata.

Tahwin, M. 2003. “Pengembangan Obyek Wisata Sebagai Sebuah Industri Studi Kasus Kabupaten Rembang." Jurnal Gemawisata 1: 236-49.

Seetanah, D, J. T., J, L. M., S, R., V, S. R., \& U, S. A. (2011). Does Infrastructure Matter In Tourism Development? UNIVERSITY OF MAURITIUS RESEARCH JOURNAL, 17(January).

Syahadat, Epi (2011). Faktor - Faktor Yang Mempengaruhi Kunjungan Wisatawan Di Taman Nasional Gede Pangrango, Jurnal Pariwisata Indonesia, Vol. 3 No.1 : 13-34, Maret 2008

Wahab, Salah. 2003. Manajemen Kepariwisataan. Vol. 2003. Jakarta: Pradnya Paramita. doi:1992.

Widiastuti, Ni Komang, Pengaruh Sektor Pariwisata Terhadap Kinerja Keuangan Daerah Dan Kesejahteraan Masyarakat Kabupaten/Kota Di Provinsi Bali, Fakultas Ekonomi Universitas Udayana (Unud), 2010.

Yoeti, Oka. A. 2003. Ekonomi Pariwisata: Introduksi, Informasi, Dan Implementasi. Jakarta: PT Kompas Media Nusantara 